\title{
Analysis of Female Interest in Maritime Education at Nikola Vaptsarov Naval Academy Varna and at the Faculty of Maritime Studies, University of Split
}

\author{
Blagovest Belev ${ }^{a}$, Gorana Jelić Mrčelićb Zdeslav Jurićb, \\ Ivan Karinc
}

The promotion of gender equality and women's empowerment is one of the main goals of the United Nations. The aim of this study is to analyze the gradual change of conservative perceptions about the role of women in shipping. Maritime education and training institutions are fully involved in the process. The Nikola Vaptsarov Naval Academy and the Split University's Faculty of Maritime Studies are a part of this process of general change in human attitude towards the acceptance of women on merchant ships. Data on female admittance and graduation are collected by both academies. In the period examined, i.e. 2012 - 2018, 129 women were enrolled at and 60 graduated from the NVNA. 281 women were enrolled at and 68 graduated from the Faculty of Maritime Studies. The attitudes of female candidates at the academy Nikola Vaptsarov were studied by means of a questionnaire. The growing number of female candidates at Nikola Vaptsarov's Navigation,

\section{KEY WORDS}

$\sim$ Women

$\sim$ Maritime professions

$\sim$ Maritime education

\author{
a. Nikola Vaptsarov Naval Academy, Varna, Bulgaria \\ e-mail: bl.belev@naval-acad.bg \\ b. University of Split, Faculty of Maritime Studies, Split, Croatia \\ e-mail: gorana.jelic@pfst.hr \\ c. Plovput d.o.o., Split, Croatia \\ e-mail: ivan.karin@plovput.hr \\ doi: 10.7225/toms.v09.n02.016
}

This work is licensed under (cc) BY
Ship Engineering and Electrician studies proves that a competitive environment was created on a completely new basis, namely the ability of women to work at an equal footing with men in a purely male-dominated profession. This paper opens the door to future research of the recruitment market required to establish the reasons behind skepticism about women on board and the ways to overcome this conservative line of thinking.

\section{INTRODUCTION}

Up until the 19th century, women had very few rights, due to religious, political or national reasons. Guided by the idea of equality between men and women and the elimination of discrimination, the International Labor Organization (ILO) adopted the Declaration of the Missionary Mission and the Purposes of the ILO in 1944. The Declaration states that "all human beings, irrespective of race, creed or sex, have the right to pursue their material well-being and their spiritual development in conditions of freedom and dignity, of economic security and equal opportunity" (ILO, 2020, page 1). For ILO, women's rights are an integral part of the values, principles and goals of the promotion of social justice and decent work (ILO, 2007). Globally, men are more likely to be part of the workforce than women. A United Nations (2015) report shows that $77 \%$ of men and $50 \%$ of women of working age are employed.

In maritime industry, one of the biggest challenges is ensuring diversity in seafarer hiring, including the hiring of women and other under-represented groups (Safety4sea, 2020). All seafarers regardless of race, color, sex, religion, 
political opinion, national extraction or social origin, as well as nationality, gender and sexual orientation have the right to equal opportunities and treatment. Today, women account for only 2 percent of the world's 1.2 million seafarers and 94 percent of female seafarers work in the cruise industry (IMO, 2020). Though women often graduate from their maritime education and training institutions with excellent results, their job applications are sometimes systematically turned down. Finding female workers at sea is still rare, but an increasing number of women are confronting prejudice and becoming valuable members of ship crews with the help of the trade unions (ITF, 2019).

Within this historically male-dominated industry, the International Maritime Organization (IMO) is making a concerted effort to help the industry move forward and supports women in the achievement of representation that is in keeping with twenty-first century expectations (IMO, 2019).

In 1988, the IMO adopted a Strategy on the Integration of Women in the Maritime Sector, based on the United Nation's (UN) policy on the development of female human resources and to strengthen the role of women (IMO, 1988).

In 1989 (IMO), launched the IMO Women in Development Program (WID) that aimed at expanding women's capabilities in the maritime sector. The program focused on equal access to maritime training through both mainstream programs and gender specific projects (Lares, 2017). According to Lares (2017), the World Maritime University (WMU), the postgraduate maritime university founded by IMO, has put in place its own policies to promote the participation of women in the maritime transport sector.
The IMO has facilitated the creation of professional networks to improve gender balance in the shipping industry. Women in Maritime Associations (WIMAs) launched the following associations in the new century through IMO's gender and capacity-building program:

1. Pacific Women in Maritime Association (PacWIMA) set up in Fiji in February 2004 and relaunched in Tonga in April 2016.

2. Network of Professional Women in the Maritime and Port Sectors for West and Central Africa launched in Benin in February 2007, set for a relaunch in 2019.

3. Association for Women in the Maritime Sector in Eastern and Southern Africa (WOMESA) established in Kenya in December 2007.

4. Women in Maritime Association, Asia (WIMA Asia) established in January 2010 and relaunched in the Philippines in 2015.

5. Women in Maritime Association, the Caribbean (WiMAC), set up in Jamaica in April 2015.

6. The Arab Association for Women in the Maritime Sector (AWIMA), established in Egypt in October 2017. The second AWIMA conference will be held in Egypt in the first quarter of 2019.

7. Red de Mujeres de Autoridades Marítimas de Latinoamérica (Red-MAMLa), established in Chile in December 2017. (Figure 1).

Women's International Shipping \& Trading Association (WISTA) is an international networking organization whose mission is to attract and support women at the management level, in the maritime, trading and logistics sectors (WISTA, 2020).
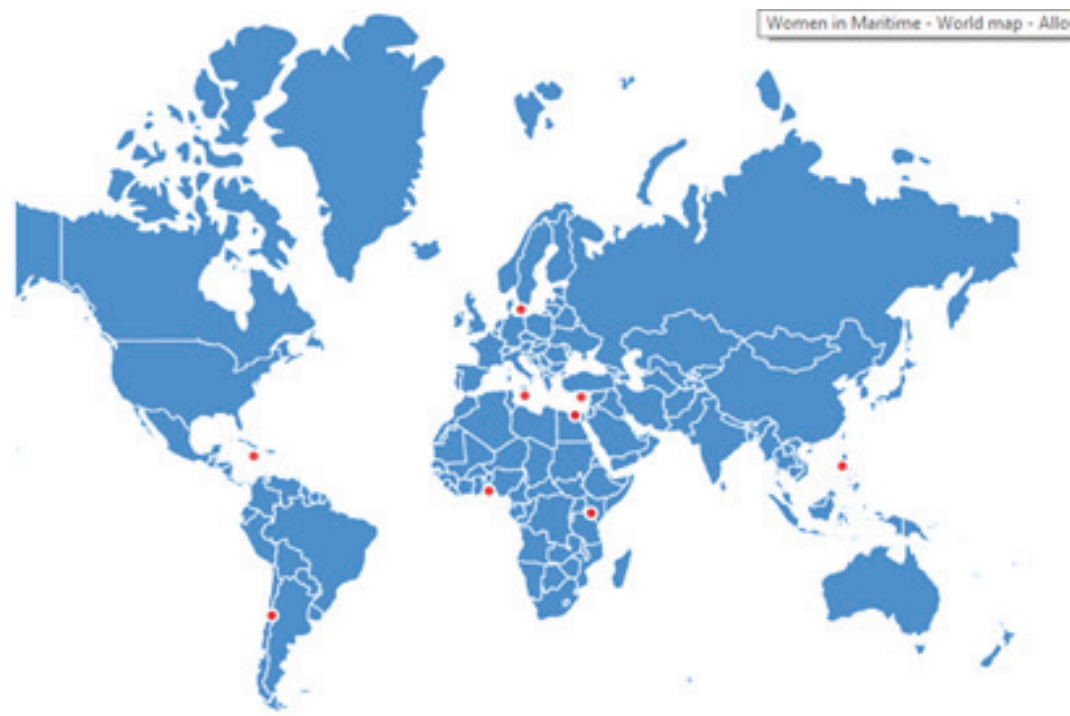

Figure 1.

Women in Maritime Associations - World map.

Source: http://www.imo.org/en/OurWork/TechnicalCooperation/Pages/WomenInMaritime.aspx 
The 2016 amendments to the 2006 Maritime Labor Convention include a reference to the ICS (International Chamber of Shipping)/ITF (International Transport Workers' Federation) Guidance on eliminating shipboard harassment and bullying. "The operationalization of the guidance and its practical implementation at the national level can help change shipboard cultures and develop a working environment in which all seafarers are treated with dignity and respect. Effective policies and timely response to complaints relating to harassment and bullying would render the industry more attractive to potential seafarers" (ILO, 2019, page 5). The IMO fosters the view that both government and industry should provide men and women equal access to and opportunity for maritime training, jobs and employment. The Organization recommends facilities suitable for women on board ships. Under the 2010 Manila Amendments to the International Convention on Standards of Training, Certification and Watch-keeping for Seafarers (STCW), resolution 14 regulates the promotion of female participation in the maritime industry (IMO, 2012).

The research on gender differences in maritime education and industry, especially onboard ships, is still rare in spite of its importance. Existing papers have raised the issue of the need to overcome gender segregation (Kitada, 2013; Belcher et al., 2003; Zhao, 1998). The leading institution in this field is the WMU, where numerous Master's and PhD theses have been written (Tifuh, 2014; Aggrey, 2000). The purpose of the study was to make an initial assessment of the women's attitudes towards working and living in a new and unusual environment at two maritime education institutions: the Nikola Vaptsarov Naval Academy (NVNA) and the Faculty of Maritime Studies, University of Split (FMS). NVNA and FMS are important stakeholders in the process of evolution of the equal treatment of men and women in maritime education and industry. Since 2009, women at NVNA have been eligible for admittance at courses Navigation, Ship Power Plants and Electrical Engineering. In 2011, the NVNA Academic Council decided to abolish quotas for male and female candidates. This act aimed to eliminate the restrictions on the training of women on an equal footing with men. At the FMS, there have never been any men/women admission quotas, nor any kind of limitation for the admission of women. This paper exposes the change of the process of admittance and graduation of women in the NVNA and the FMS.

\section{RESEARCH METHODS}

To gain a clear understanding of the intentions of women candidates for work on board merchant ships, a survey was conducted at the NVNA in the framework of several campaigns. To make their proposals to the applicants more persuasive, they conducted the survey in cooperation with the studying department, which is entirely responsible for conducting the admission campaign, using the interview method.

349 female applicants were interviewed in 2009 - 2013. Perspective students of all specialties were asked the following questions:

1. Do you intend to apply for study in any of the specialties: Navigation, Ship Engineers or Electrical Engineers?

2. If you are admitted to one of the three specialties and successfully graduate, do you plan to work on a merchant ship?

3. Would you consent to working with a male team?

4. Do you believe that physically and mentally you can take 4-5 months away from home?

5. Do you believe you can handle being managed by a male team?

The candidates had to choose one of the two possible answers - negative (No) or positive (Yes).

Apart from NVNA's questionnaire on the attitudes of female applicants about these 5 questions, similar data have been requested at both the NVNA and the FMS in 2012-2018.

\section{RESULTS}

Figure 2 presents results of the questionnaire used to examine the attitudes of 349 female applicants at the NVNA in 2009-2013.

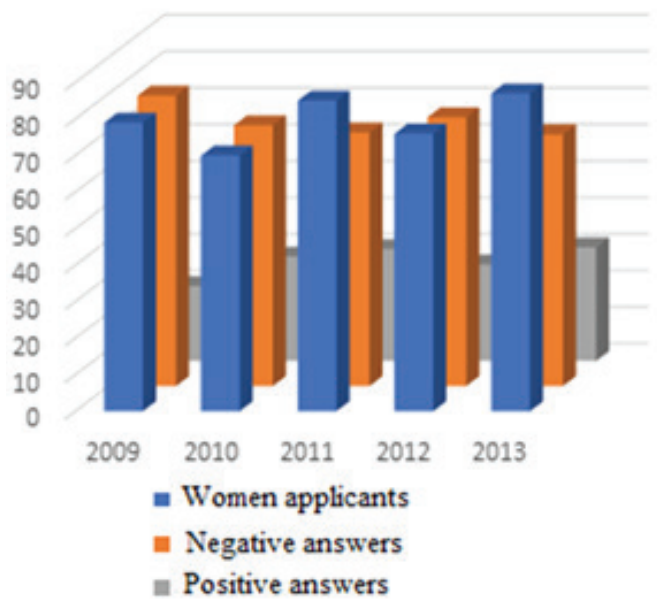

Figure 2.

Results of the survey of women applicants' attitudes in 20092013.

The results fluctuated between $70 \%$ and $90 \%$ in the period studied. In 2013 an average of $79.5 \%$ of respondents gave negative answer (No) to the 5 questions in the questionnaire.

Figure $3 a$ shows female interest in seafaring professions at the NVNA. 


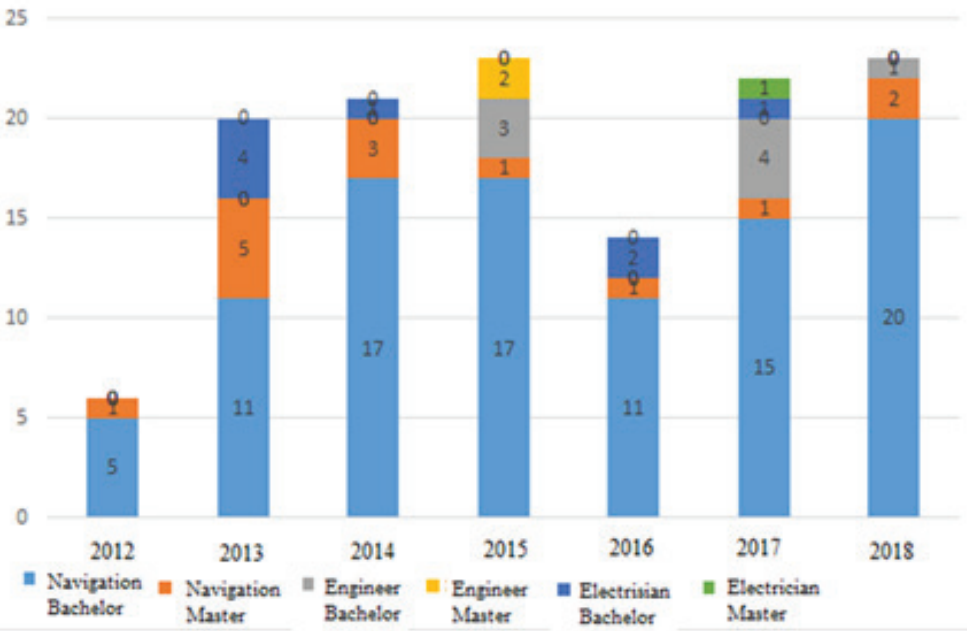

Figure $3 a$.

Number of female applicants to various studies at the NVNA in 2012-2018.

There is a growing interest of female applicants in all studies (from 6 female applicants in 2012 to 23 female applicants in 2018), but especially in Navigation (from 5 female applicants in 2012 to 20 female applicants in 2018).
Figure $3 \mathrm{~b}$ shows female interest in seafaring professions at the FMS.

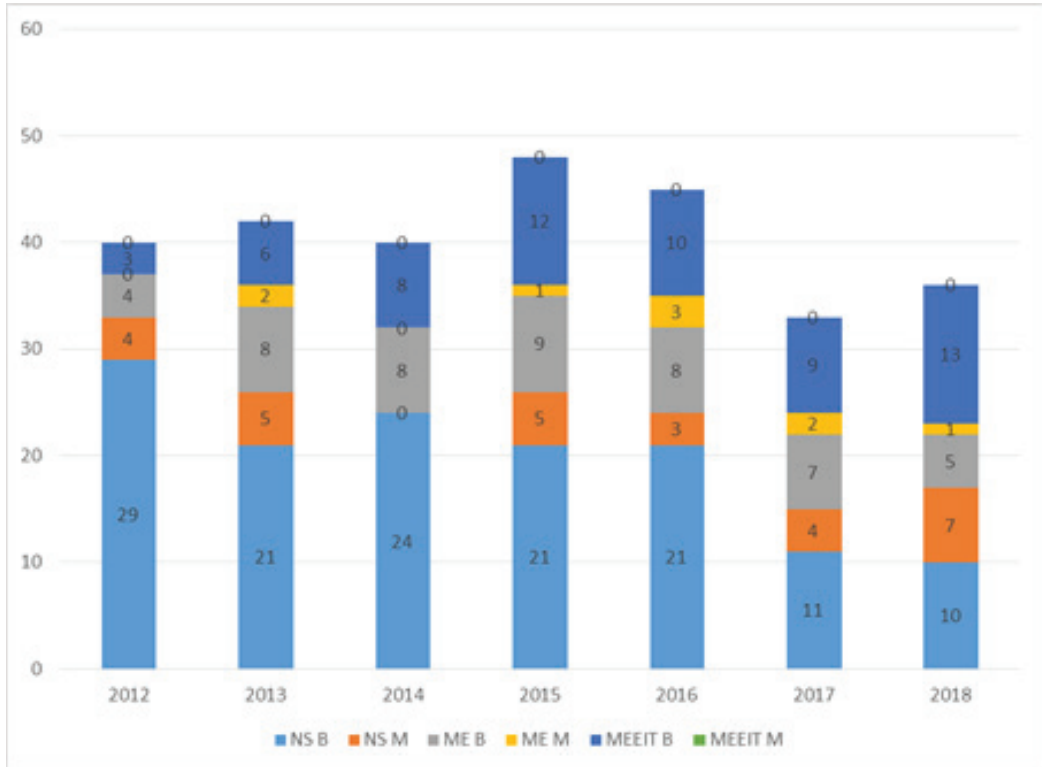

Figure $3 b$.

Number of female applicants to various studies at the FMS from 2012 to 2018 (NS Nautical Studies, ME Marine Engineering, MEEIT Marine Electrical Engineering and Information Technologies, B - Bachelor, $\mathrm{M}$ - Master). 
The interest of female applicants for Nautical Studies has decreased from 29 female applicants for Nautical Studies Bachelor's degree (NS B) in 2012 to only 10 female applicants in 2018. The interest of female applicants in Marine Electrical Engineering and Information Technologies has increased from three female applicants in 2012 to 13 female applicants in
2018. The number of women applicants to Marine Engineering Studies has fluctuated between four (minimum in 2012) and nine candidates (maximum in 2015).

Figure $4 a$ shows the number of female graduates at the NVNA.

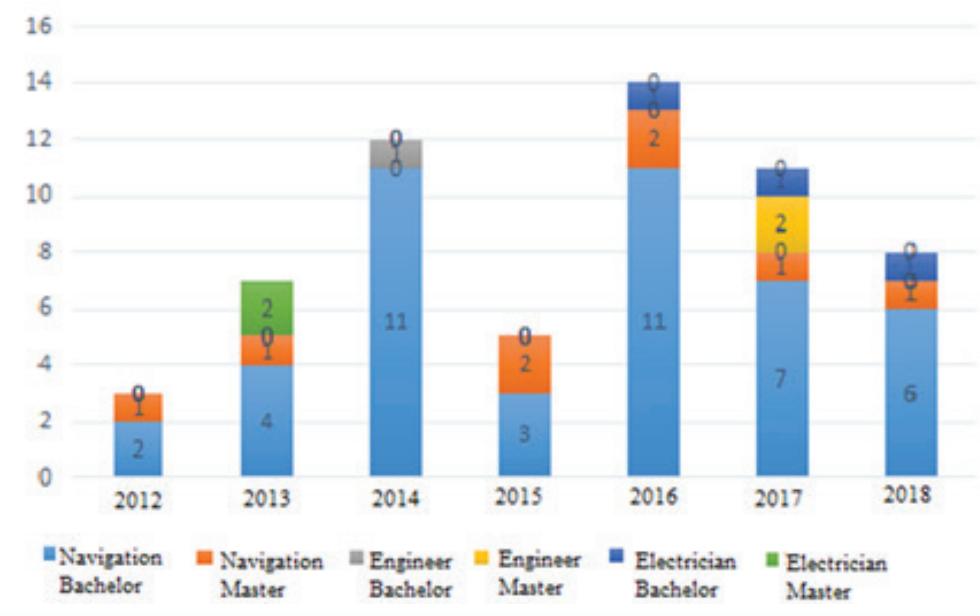

Figure $4 a$.

Number of female graduates at various NVNA courses from 2012 to 2018.

The number of female graduates has fluctuated between three graduates (minimum) in 2012 and 14 graduates (maximum) in 2016. By far the greatest number of women graduated in
Navigation (between 2 female graduates (minimum) in 2012 to 11 female graduates (maximum) in 2014 and 2016).

Figure $4 \mathrm{~b}$ shows the number of female graduates at the FMS.

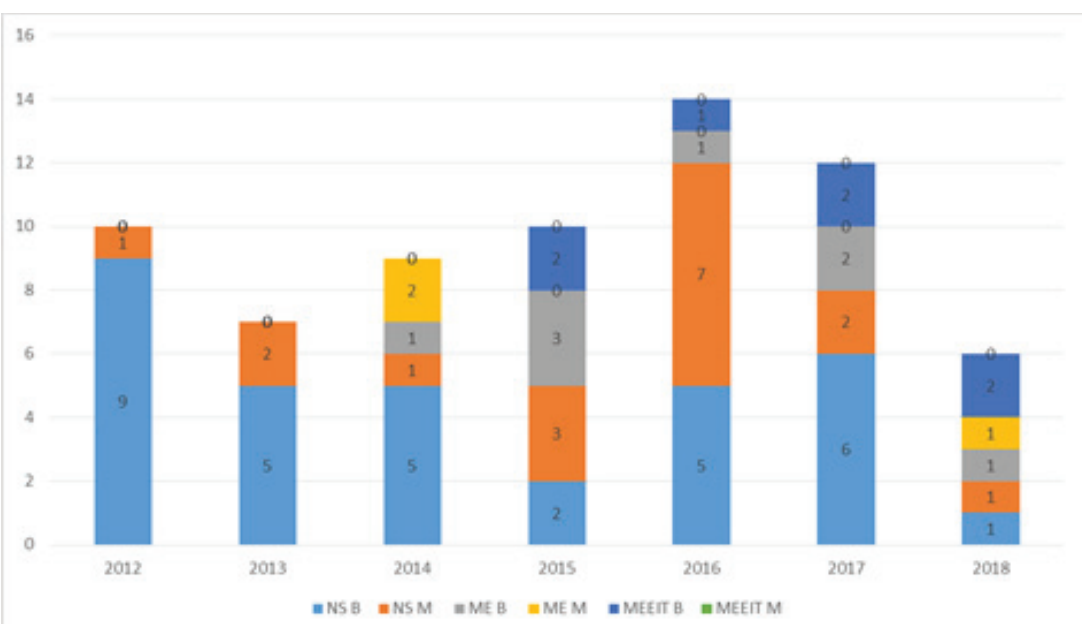

Figure $4 b$.

Number of female graduates at various courses at the FMS in 2012-2018 (NS Nautical Studies, ME Marine Engineering, MEEIT Marine Electrical Engineering and Information Technologies, B - Bachelor, M - Master). 
The number of female graduates is considerably smaller than the number of women enrolled in the observed period: 9 female graduates for NS B in 2012 and only 1 in 2018; between 0 and 3 women graduated in ME $B$ and between 0 and 2 in MEEIT $B$.

\section{DISCUSSION}

This paper explains the change in the process of admittance and graduation of women at the NVNA and the FMS. Women have been eligible for admittance at the courses Navigation, Ship Power Plants and Electrical Engineering at the NVNA since 2009, and the NVNA Academic Council decided to abolish the quotas for male and female candidates in 2011. At the FMS, there have never been any male/female admission quotas, nor any kind of limitation for female enrollment.

Figure 2 presents the results of the questionnaire used to establish the attitudes of 349 female applicants at the NVNA in 2009-2013. There is a tendency for a slow but lasting reduction of the negative (No) answers compared to the number of students, and a gradual increase in the specialties of interest. This tendency reflects the gradual change in female applicants' attitudes on the role of women in the maritime sector.

Figure 3a shows women's persistent interest in seafaring professions at the NVNA. Allowing female enrollment at the so-called regulated specialties - Navigation, Ship Engineer and Electrician - at the NVNA in 2011 has increased the interest of female applicants from 6 female applicants in 2012 to 23 female applicants in 2018. There is a growing interest of female applicants especially for the Navigation specialty (from 5 female applicants in 2012 to 20 female applicants in 2018), probably due to the idea that the captain's profession is more prestigious and perhaps more appropriate for women. This statistic does not include the number of interrupted studies.

Figure 3b. shows women's interest in seafaring professions at the FMS. The interest of female applicants for Nautical Studies has decreased from 29 in 2012 to 10 in 2018, while the interest of female applicants for Marine Electrical Engineering and Information Technologies has increased from 3 female applicants in 2012 to 13 female applicants in 2018. The number of female applicants to Marine Engineering Studies has fluctuated between 4 and 9 candidates in the observed period. The steady interest in Marine Engineering Studies stems from the high demand for engine officers and IT experts on the maritime and global labor market in general and easy conversion to on-shore jobs

Figure 4a. shows the number of female graduates. The number has fluctuated between 3 graduates (minimum) in 2012 and 14 graduates (maximum) in 2016. By far the greatest number of women at the NVNA graduated in Navigation (between 2 in 2012 and 11 in 2014 and 2016).
Five of 12 female graduates at the NVNA are active deck officers, engineers and electricians. The reasons are various and include:

1. female awareness of difficulties of life on board including fear of sexual comments, sexual abuse and any unwanted physical contact on board;

2. negative attitude of some recruitment companies to women onboard - they openly refuse to hire women on merchant ships.

Equal education and the promotion of equal employment opportunities, including in leadership roles, will ensure that the best possible candidate gets the job (MacNeil and Ghosh, 2017). Dragomir and Utureanu (2018) are of the opinion that shipping companies should update their human resources policies by making them gender-friendly and ensuring that policies on gender equality and cultural awareness are communicated on board their ships, in the on-shore headquarters of the company, to various stakeholders and to the community through their websites and the social media.

According to the Ministry of Labor and Social Policy of the Republic of Bulgaria, there were 86 registered recruitments of maritime specialists (MLSP, 2019). 21 of these are most active in the labor market for seafarers in commercial shipping. According to the Croatian Ship Manning Association, there are 23 crewing agencies active in Croatia (CROSMA, 2020), and according to the Ministry of the Sea, Transport and Infrastructure of the Republic of Croatia (MSTI, 2020) there are 41 crewing agencies, 8 employers and 6 shipping companies that are also registered for recruitment activities. The statistics show that the number of women is low compared with the number of men employed in such companies.

Figure $4 b$ shows the number of female graduates at the FMS. The number of female graduates is much smaller compared to the number of women admitted in the observed period: 9 female graduates in NS B in 2012 and only 1 in 2018; between 0 and 3 female graduates in ME $B$ and between 0 and 2 in MEEIT $B$. The percentage of women who graduated/were admitted is also smaller at the FMS than at the NVNA. At the FMS, the drop off rate is high as a large percentage of students enroll at the FMS only to receive students' grants.

The Bachelor Studies last for 4 years and Master Studies for 1.5 years at the NVNA, while the Bachelor Studies last for 3 years and Master Studies for 2 years at the FMS. During the period 2012-2018, 129 women enrolled at and 60 graduated from the three study programs at both levels at the NVNA. In that same period, 281 women enrolled at and 68 graduated from the three study programs (excluding women admitted and graduated from two other study programs - Maritime Management Studies and Maritime Yacht and Marina Technologies Studies) at both 
levels at the FMS. The number of graduates does not include the 82 women admitted to the NVNA during the last 4 years and 112 women admitted to the FMS during the last 3 years. These numbers are high and there is a potential for these female students to change the image of the industry both in Bulgaria and Croatia upon successful graduation, but also worldwide. The growing number of female candidates for Navigation, Ship Engineer and Electrician creates a competitive environment on a completely new basis - the ability of women to work on an equal footing with men in a previously purely male profession.

Maritime education in Bulgaria dates back to 1881. Towards the end of the $20^{\text {th }}$ century, the trainees were men. Worldwide changes over the last three decades have changed the perception of shipping traditions. Since the second half of the $20^{\text {th }}$ century there have been examples of female captains, mechanics and electrical engineers in the Bulgarian merchant fleet. But they are exceptions rather than a rule. The reasons why women have not been part of a ship's crew are essentially physiological and emotional. Attempts and efforts to achieve gender equality have enabled women to look at male professions and declare a desire to seek realization by breaking the rules. In Croatia, the oldest naval academy originates from 1866. The FMS was inaugurated in 1959.

Maritime education and training is crucial for shaping future gender and culture-sensitive seafarers. MET institutions are expected to play multifaceted roles in the education and training of maritime students. Four important roles include:

1. serving as a training ground for future men and women who are expected to be equipped with technical knowledge, skills and attitude as part of the formulaic triad of competencies;

2. raising future seafarers with sensitive minds and character, more aware of life at sea and having them understand and be adaptive to diverse cultural orientations;

3. developing a mindset that erases gender biases and rises above cultural differences;

4. raising gender and cultural awareness by integrating such ideals in their curriculum and instruction (GECAMET, 2018).

The recruitment process starts with education and training. It is necessary to motivate women to pursue career paths in the maritime and ocean fields as early as possible in their education (Doumbia-Henry, 2019). According to Cars and Österman (2015), increasing the number of female students will not close the gender gap in the maritime industry on its own. Gender issues must be well-defined, operationalized and included in educational policy and curricula-making at individual, structural, as well as at the symbolic level. Horck (2010a) advises educational institutions to publish a university policy on the gender perspective and diversity management in general. It should be made in written form and posted in a public place to be understood and remembered by staff and students.
According to Dragomir et al. (2018) the MET curriculum should include specific courses on female leadership, gender equality and cultural communication to develop leadership skills in women. Horck (2010b) also recommends maritime education and training institutions to offer courses on cultural, as well as courses on pedagogical (andragogical) awareness to students when women start to take up studies in maritime subjects.

Violeta Bulc, EU Commissioner for Transport (Safety4sea, 2018), claims that an increasing number of organizations are showing interest in addressing and providing solutions to gender equality in shipping by mentoring, coaching and/ or training women. A new Leadership in the Public Sector course is being developed by the United Nations Institute for Training and Research (UNITAR) to support the United Nations Sustainable Development Goal of achieving gender equality and empowering all women and girls (SDG5).

MacNeil and Ghosh (2017) recommend international organizations to conduct further research/studies to identify upto-date statistical information on women in the maritime industry. Future research on this topic will highlight the employment rate of women in the sector and outline the problems faced by both sides in the process.

\section{CONCLUSION}

The Bachelor Studies last for 4 years and Master Studies for 1.5 years at the NVNA, while the Bachelor Studies last for 3 years and Master Studies for 2 years at the FMS. During the period 2012-2018, 129 women enrolled at and 60 graduated from the three study programs at both levels at the NVNA. In that same period, 281 women enrolled at and 68 graduated from the three study programs (excluding women admitted and graduated from two other study programs - Maritime Management Studies and Maritime Yacht and Marina Technologies Studies) at both levels at the FMS. The number of graduates does not include the 82 women admitted to the NVNA during the last 4 years and 112 women admitted to the FMS during the last 3 years. These numbers are high and there is a potential for these female students to change the image of the industry both in Bulgaria and Croatia upon successful graduation, but also worldwide. The growing number of female candidates for Navigation, Ship Engineer and Electrician creates a competitive environment on a completely new basis - the ability of women to work on an equal footing with men in a previously purely male profession.

\section{REFERENCES}

Aggrey H., 2000. Women in Maritime Industry: A Review of Female Participation and their Role in Maritime Education and Training in the 21st Century, Master thesis, World MaritimeUniversity, Sweden. 
Belcher P., Sampson H., Thomas M., Zhao M., 2003. Women Seafarers. Global Employment Policies and Practice. 1st ed., Geneva, International Labour Office.

Cars, M.B. \& Österman, C., 2015. Mind the Gap! Maritime Education for Gender-Equal Career Advancement. WMU Studies in Maritime Affairs, pp.143-153. Available at: http://dx.doi.org/10.1007/978-3-662-45385-8_11.

CROSMA, 2020. Croatian Ship Manning Association. Available at: https://www. crosma.hr/en/, accessed on: 03 February 2020.

Doumbia-Henry, C., 2019. Foreword for JOMA December 2019-empowering women in the maritime community: the way ahead. WMU Journal of Maritime Affairs, 18(4), pp.521-524. Available at:

http://dx.doi.org/10.1007/s13437-019-00187-7.

Dragomir, C. \& Utureanu S. L., 2018. Gender in Maritime Transport - A Scientific Literature Overview. Ovidius University Annals, Economic Sciences Series, 18(1), pp.158-163.

Dragomir, C. et al., 2018. Women Leaders in Shipping as Role Models for Women Seafarers. TransNav, the International Journal on Marine Navigation and Safety of Sea Transportation, 12(2), pp.279-284. Available at: http://dx.doi.org/10.12716/1001.12.02.07.

GECAMET, 2018. Gender Equality and Cultural Awareness in Maritime Education and Training, IAMU 2017 Research Project (No. 20170305), Constanta Maritime University.

Horck, J., 2010a. The gender perspective in maritime education and training. WMU Journal of Maritime Affairs, 9(1), pp.93-119. Available at: http://dx.doi.org/10.1007/bf03195168.

Horck J., 2010b. Meeting Diversities in Maritime Education, a blend from World Maritime University. Doctoral thesis, World Maritime University, Sweden.

ILO, 2020. Declaration concerning the aims and purposes of the International Labor Organization (DECLARATION OF PHILADELPHIA). Available at: https://www.ilo.org/ wcmsp5/groups/public/---asia/---ro-bangkok/---ilo-islamabad/documents/policy/ wcms_142941.pdf, accessed on: 06 May 2020.

ILO, 2019. Sectoral Meeting on the Recruitment and Retention of Seafarers and the Promotion of Opportunities for Women Seafarers. Available at: https://www.ilo.org/ sector/activities/sectoral-meetings/WCMS_647753/lang--en/index.htm, accessed on: 03 February 2019.

ILO, 2007. ABC of women workers' rights and gender equality. 2nd Ed., Geneva: International Labor Office.

IMO, 2020. Available at: http://www.imo.org/en/OurWork/Technical Cooperation/ Pages/WomenlnMaritime.aspx, accessed on: 23 January 2019.

IMO, 2012. A study towards development of a Strategy for women seafarers, submitted by the Republic of Korea. Integration of Women in the Maritime Sector, (TC
62/8/1). Available at: http://docs.imo.org/Search.aspx?keywords=\%22women $\% 20$ seafarers\%22, accessed on: 03 February 2019.

IMO, 1988. Strategy for the integration of women in the maritime sector. Available at: http://www.imo.org/en/OurWork/TechnicalCooperation/Pages/WomenInMaritime. aspx , accessed on: 03 February 2019.

ITF, 2019. Women Seafarers, Available at: https://www.itfseafarers.org/ITI-womenseafarers.cfm, accessed on: 13 March 2019.

Kitada, M., 2013. Code of behaviour at sea: women seafarers' shipboard identity management. WMU Journal of Maritime Affairs, 12(2), pp.213-227. Available at: http://dx.doi.org/10.1007/s13437-013-0044-7.

Romero Lares, M.C., 2017. A Case Study on Gender Equality and Women's Empowerment Policies Developed by the World Maritime University for the Maritime Transport Sector. TransNav, the International Journal on Marine Navigation and Safety of Sea Transportation, 11(4), pp.583-587. Available at: http://dx.doi.org/10.12716/1001.11.04.02.

MacNeil, A. \& Ghosh, S., 2016. Gender imbalance in the maritime industry: impediments, initiatives and recommendations. Australian Journal of Maritime \& Ocean Affairs, 9(1), pp.42-55. Available at: http://dx.doi.org/10.1080/18366503.2016.1271262.

MLSP, 2019. Ministry of Labor and Social Policy of the Republic of Bulgaria, Employment Agency. Available at: https://www.az.government.bg/intermediaries/ intermediary_activity/marine/ ?page=1, accessed on: 13 March 2019.

MSTI, 2020. Ministry of the Sea, Transport and Infrastructure of the Republic of Croatia, 2020. Available at: https://mmpi.gov.hr/more-86/pomorci-112/ zaposljavanje/1278, accessed on: 06 February 2020.

Safety4sea, 2018. Available at: https://safety4sea.com/women-maritimeencourage-participation/,accessed on: 06 May 2020

Safety4sea, 2020. Available at: https://safety4sea.com/ilo-recommendations-toensure-equal-opportunities-for-seafarers/, accessed on: 06 May 2020.

Tifuh, A.N., 2014. Women merchant mariners: empowering West African women, World Maritime University Dissertations. 482. Available at: http://commons.wmu. se/all_dissertations/482, accessed on: 23 January 2019.

UNITED NATIONS, 2015. The World's Women 2015: Trends and Statistics. New York: United Nations, Department of Economic and Social Affairs, Statistics Division.

WISTA, 2020. Available at: https://wistainternational.com/, accessed on: 06 May 2020.

Zhao M., 1998. Women Seafarers in the EC: A Preliminary Report Based on German and UK Case Studies, 1st ed., Cardiff, Seafarers International Research Center. 